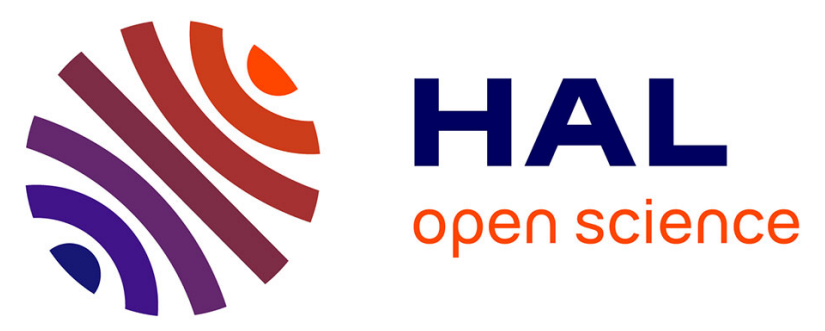

\title{
In vivo and in vitro 31P-NMR Study of the Phosphate Transport and Polyphosphate Metabolism in Hebeloma cylindrosporum in Response to Plant Roots Signals
}

Christine Le Guerneve, Adeline Becquer, Margarita Torres Aquino, Laurie Amenc, Carlos Trives Segura, Siobhan Staunton, Claude Plassard, Herve Quiquampoix

\section{To cite this version:}

Christine Le Guerneve, Adeline Becquer, Margarita Torres Aquino, Laurie Amenc, Carlos Trives Segura, et al.. In vivo and in vitro 31P-NMR Study of the Phosphate Transport and Polyphosphate Metabolism in Hebeloma cylindrosporum in Response to Plant Roots Signals. Bio-protocol , 2018, 8 (16), 10.21769/BioProtoc.2973 . hal-02618473

\section{HAL Id: hal-02618473 \\ https://hal.inrae.fr/hal-02618473}

Submitted on 25 May 2020

HAL is a multi-disciplinary open access archive for the deposit and dissemination of scientific research documents, whether they are published or not. The documents may come from teaching and research institutions in France or abroad, or from public or private research centers.
L'archive ouverte pluridisciplinaire HAL, est destinée au dépôt et à la diffusion de documents scientifiques de niveau recherche, publiés ou non, émanant des établissements d'enseignement et de recherche français ou étrangers, des laboratoires publics ou privés. 


\section{In vivo and in vitro ${ }^{31} \mathrm{P}-\mathrm{NMR}$ Study of the Phosphate Transport and Polyphosphate Metabolism in Hebeloma cylindrosporum in Response to Plant Roots Signals \\ Christine Le Guernevé ${ }^{1, *}$, Adeline Becquer ${ }^{2}$, Margarita Torres-Aquino ${ }^{2, \$}$, Laurie K Amenc ${ }^{2}$, Carlos Trives-Segura², Siobhan Staunton ${ }^{2}$, Claude Plassard² and Hervé Quiquampoix ${ }^{2, *}$}

${ }^{1}$ INRA, UMR SPO (1083) Sciences pour l'Oenologie, Montpellier, France; ${ }^{2}$ INRA, UMR Eco\&Sols, Montpellier, France; ${ }^{\$}$ Present address: Colegio de Postgraduados, Campus San Luis Potosí, Agustín de Iturbide No 73, Salinas de Hidalgo, Salinas, S.L.P, México, Mexico

*For correspondence: herve.quiquampoix@inra.fr; christine.le-guerneve@inra.fr

[Abstract] We used in vivo and in vitro phosphorus-31 nuclear magnetic resonance $\left({ }^{31} \mathrm{P}-\mathrm{NMR}\right)$ spectroscopy to follow the change in transport, compartmentation and metabolism of phosphate in the ectomycorrhizal fungus Hebeloma cylindrosporum in response to root signals originating from host (Pinus pinaster) or non-host (Zea mays) plants. A device was developed for the in vivo studies allowing the circulation of a continuously oxygenated mineral solution in an NMR tube containing the mycelia. The in vitro studies were performed on fungal material after several consecutive treatment steps (freezing in liquid nitrogen; crushing with perchloric acid; elimination of perchloric acid; freeze-drying; dissolution in an appropriate liquid medium).

Keywords: ${ }^{31} \mathrm{P}-\mathrm{NMR}$ spectroscopy, Phosphate compartmentation, Polyphosphate metabolism, Ectomycorrhizal fungi

[Background] The association between mycorrhizal fungi and plants improves the $\mathrm{P}$ nutrition of the host-plant (Smith and Read, 2008; Plassard and Dell, 2010; Cairney, 2011; Smith et al., 2015). This positive effect has been attributed primarily to phosphate $(\mathrm{Pi})$ uptake by the fungal hyphae exploring a large volume of soil beyond the depletion zone around actively absorbing roots (Smith and Read, 2008; Cairney, 2011; Smith et al., 2015) and to the secretion of extracellular phosphatases by the fungal cells (Quiquampoix and Mousain, 2005). Absorbed $\mathrm{Pi}$ is partly incorporated into phosphorylated metabolites, phospholipids and nucleic acids, and partly condensed into polyphosphates (PolyP) where they constitute a storage pool in the vacuoles (Ashford et al., 1994). This protocol details a device that allows the study of $\mathrm{Pi}$ transport in fungal cell compartments and metabolism of PolyP by ${ }^{31} \mathrm{P}-\mathrm{NMR}$ spectroscopy. Mycelia are incubated without plants, with host plants or with non-host plants (Torres-Aquino et al., 2017). For the in vivo studies, this perfusion system permits the circulation of an oxygenated nutrient solution in an NMR tube so that the risk of liquid leakage in the NMR spectrometer is prevented. The in vitro studies are based on the perchloric acid extraction of the fungal mycelia. This protocol could be used for other fungal or plant species. 


\section{Materials and Reagents}

1. 50 ml Falcon ${ }^{\circledR}$ tube (Corning, catalog number: 352098 )

2. Sterile plastic Petri dish, $90 \mathrm{~mm}$ (Dominique DUTSCHER, Gosselin, catalog number: 688302)

3. Sterile plastic Petri dish, $35 \mathrm{~mm}$ (Corning, Falcon ${ }^{\circledR}$, catalog number: 351008 )

4. Nichrome wire, stainless steel, round, 22 gauge, $0.64 \mathrm{~mm}$ diameter (suppliers for electronic cigarettes)

5. Aluminum screw cap, $40 \mathrm{~mm}$ with rubber liner (VWR, SPV, catalog number: 215-2690)

6. Multi-Purpose Silicone for kitchen or bathroom, $280 \mathrm{ml}$ (Castorama, Rubson)

7. $60 \mathrm{ml}$ Luer-lock syringes (B. Braun Melsungen, Omnifix ${ }^{\circledR}$, catalog number: $4613503 \mathrm{~F}$ )

8. Teflon ${ }^{\mathrm{TM}}$ PTFE microtube, $1.15 \mathrm{~mm}$ and $1.75 \mathrm{~mm}$ for internal (int) and external (ext) diameter (diam), respectively (Dominique DUTSCHER, PTFE, catalog number: 091932)

9. Needles $18 \mathrm{G} 0.9 \times 40 \mathrm{~mm}$ (Dominique DUTSCHER, BD Microlance ${ }^{\mathrm{TM}} 3$, catalog number: 301300)

10. Tubing, int diam $1.14 \mathrm{~mm}$ (Dominique DUTSCHER, Silicone, catalog number: 4906591)

11. Tubing, int diam $3.17 \mathrm{~mm}$ (Dominique DUTSCHER, Silicone, catalog number: 4906600)

12. Tubing, int diam $2.79 \mathrm{~mm}$ (Gilson, PVC, catalog number: F117948)

13. Microtubes, $1.5 \mathrm{ml}$ (Dominique DUTSCHER, Eppendorf, catalog number: 033511)

14. Straight barbed reducing connectors (Cole-Parmer, catalog number: EW-50621-95)

15. Valve Luer polycarbonate one way (Cole-Parmer, catalog number: EW-30600-01)

16. Sterile syringe filters for air, $0.2 \mu \mathrm{m}, 6.4 \mathrm{~cm}$ diam (Labomoderne, Midisart, catalog number: RS3320)

17. Autoclavable Polypropylene bag, 3 L, non-printed (Dominique DUTSCHER, Gosselin, catalog number: 140230)

18. Tips $1,200 \mu \mathrm{l}$ for pipet (Dominique DUTSCHER, Sartorius, catalog number: 077200B)

19. Home-made syringe holder

20. Home-made needle holder for aeration

21. Folding skirted caps, $14.9 \mathrm{~mm}$ diam (Dominique DUTSCHER, Saint Gobain, catalog number: 110602)

22. Paper for sterilization (Dominique DUTSCHER, catalog number: 006950)

23. Surgical blade sterile No 21 (Dominique DUTSCHER, catalog number: 132521)

24. Borosilicate glass capillaries with filament for easy filling, $1.5 \mathrm{~mm}$ outer diameter, $0.86 \mathrm{~mm}$ internal diameter (Harvard Apparatus, catalog number: 30-0057)

25. $10 \mathrm{~mm}$ diameter NMR tubes for in vitro studies (Norell, catalog number: 1008-UP-8)

26. Specially homemade NMR tube for in vivo studies (see Figure 1)

27. Silicone film

28. Hebeloma cylindrosporum (ectomycorrhizal basidiomycete) (laboratory's own collection, available upon request)

29. Pinus pinaster 
30. Zea mays

31. Concentrated $(30 \%)$ hydrogen peroxide $\left(\mathrm{H}_{2} \mathrm{O}_{2}\right)$ solution (Sigma-Aldrich, catalog number: 216763-500ML-M)

32. Liquid nitrogen (Air Liquide)

33. Calcium sulfate dihydrate $\left(\mathrm{CaSO}_{4} \cdot 2 \mathrm{H}_{2} \mathrm{O}\right)$ (Merck, catalog number: 102161)

34. Thiamine hydrochloride $-\mathrm{HCl}$ (Sigma-Aldrich, catalog number: T4625-10G)

35. Manganese (II) sulfate monohydrate $\left(\mathrm{MnSO}_{4} \cdot \mathrm{H}_{2} \mathrm{O}\right)$ (Sigma-Aldrich, catalog number: M7899-500G)

36. Zinc sulfate heptahydrate $\left(\mathrm{ZnSO}_{4} \cdot 7 \mathrm{H}_{2} \mathrm{O}\right)$ (Sigma-Aldrich, catalog number: Z0251-100G)

37. Boric acid $\left(\mathrm{H}_{3} \mathrm{BO}_{3}\right)$ (Sigma-Aldrich, catalog number: B6768-500G)

38. Copper (II) sulfate pentahydrate $\left(\mathrm{CuSO}_{4} \cdot 5 \mathrm{H}_{2} \mathrm{O}\right)$ (Sigma-Aldrich, catalog number: $\mathrm{C} 8027-500 \mathrm{G}$ )

39. Sodium molybdate dihydrate $\left(\mathrm{Na}_{2} \mathrm{MoO}_{4} \cdot 2 \mathrm{H}_{2} \mathrm{O}\right)$ (Sigma-Aldrich, catalog number: M1651-100G)

40. Potassium nitrate $\left(\mathrm{KNO}_{3}\right)$ (Sigma-Aldrich, catalog number: $\left.\mathrm{P} 8291-1 \mathrm{KG}\right)$

41. Sodium phosphate monobasic monohydrate $\left(\mathrm{NaH}_{2} \mathrm{PO}_{4} \cdot \mathrm{H}_{2} \mathrm{O}\right)$ (Sigma-Aldrich, catalog number: 71504-250G-M)

42. Magnesium sulfate heptahydrate $\left(\mathrm{MgSO}_{4} \cdot 7 \mathrm{H}_{2} \mathrm{O}\right)$ (Sigma-Aldrich, catalog number: 63138-250G)

43. Potassium chloride (KCl) (Sigma-Aldrich, catalog number: P9333-500G)

44. Calcium chloride dihydrate $\left(\mathrm{CaCl}_{2} \cdot 2 \mathrm{H}_{2} \mathrm{O}\right)$ (Sigma-Aldrich, catalog number: $\left.\mathrm{C} 5080-500 \mathrm{G}\right)$

45. Ferric ammonium citrate (Sigma-Aldrich, catalog number: RES20400-A702X)

46. D-glucose (Sigma-Aldrich, catalog number: G8270-1KG)

47. Agar-agar (Sigma-Aldrich, catalog number: A7002-500G)

48. MES (2-N-morpholino-ethanesulfonic acid, 4-morpholineethanesulfonic acid monohydrate) (Sigma-Aldrich, catalog number: 69892-500G)

49. Tris(hydroxymethyl)aminomethane (TRIS) (Sigma-Aldrich, catalog number: T1378-500G)

50. Methylenediphosphonic acid (MDP) (Sigma-Aldrich, catalog number: M9508-5G)

51. $1 \mathrm{~N}$ sulfuric acid solution (Merck, catalog number: 109072)

52. Perchloric acid $70 \%\left(\mathrm{HClO}_{4}\right)$ (Sigma-Aldrich, catalog number: $\left.311421-250 \mathrm{ML}\right)$

53. Sodium metavanadate $\left(\mathrm{NaVO}_{3}\right)$ (Sigma-Aldrich, catalog number: $590088-25 \mathrm{G}$ )

54. Potassium bicarbonate $\left(\mathrm{KHCO}_{3}\right)$ (Sigma-Aldrich, catalog number: 60339-500G)

55. Ethylenediaminetetraacetic acid (EDTA) (Sigma-Aldrich, catalog number: E6758-500G)

56. Potassium hydroxide $1 \mathrm{~N}(\mathrm{KOH})$ (Merck, catalog number: 105029)

57. 4-Morpholinepropanesulfonic acid (MOPS) (Sigma-Aldrich, catalog number: M1254-250G)

58. Sodium azide $\left(\mathrm{NaN}_{3}\right)$ (Sigma-Aldrich, catalog number: $\left.\mathrm{S} 2002-100 \mathrm{G}\right)$

59. Deuterium oxide $\left(\mathrm{D}_{2} \mathrm{O}\right)$ (Sigma-Aldrich, catalog number: 151882-100G)

60. Trace elements (see Recipes)

61. Mineral salt base solutions (see Recipes)

62. Thiamine solution (see Recipes)

63. N6 complete liquid solution (see Recipes) 
64. Solid N6 complete liquid solution (see Recipes)

65. Interaction medium (IM) (see Recipes)

\section{Equipment}

1. Sample bottles, $120 \mathrm{ml}$ (VWR, SPV, catalog number: SPVAGO2246)

2. Glass bottles, $1,000 \mathrm{ml}$, ISO borosilicate, graduated (Dominique DUTSCHER, catalog number: 046415)

3. Glass bottles, $2,000 \mathrm{ml}$, ISO borosilicate, graduated (Dominique DUTSCHER, catalog number: 046416)

4. Glass cylinder (diameter $7 \mathrm{~mm}$ )

5. Graduated borosilicate glass beaker $1,000 \mathrm{ml}$ (Dominique DUTSCHER, catalog number: 068942)

6. Polypropylene economical beaker 3,000 with moulded graduations (Dominique DUTSCHER, catalog number: 391134)

7. Two pairs of stainless steel straight tweezers Wironit, Brucelles type, $130 \mathrm{~mm}$ (Dominique DUTSCHER, catalog number: 491037)

8. A scalpel handle for blade 20 to 25 (Dominique DUTSCHER, catalog number: 3740004 )

9. A standalone burner (Dominique DUTSCHER, catalog number: 071109)

10. Butane gas cartridge for the burner (Dominique DUTSCHER, catalog number: 060415)

11. A nail, a hammer, scissors and cutting pliers

12. Incubator with controlled temperature set at $25^{\circ} \mathrm{C}$

13. Autoclave

14. Laminar flow cabinet

15. Cork-borer, $7.5 \mathrm{~mm}$ diameter (Dominique DUTSCHER, catalog number: 942783)

16. High pressure $\mathrm{O}_{2}$ gas cylinder (Air products)

17. Centrifuge 5804 R, refrigerated, without rotor, (Eppendorf, model: $5804 \mathrm{R}$, catalog number: 5805000017)

18. Rotor F-34-6-38, for $6 \times 85 \mathrm{ml}$ tubes, incl. rotor lid (Eppendorf, catalog number: 5804727002 )

19. Adapter for $50 \mathrm{ml}$ Falcon tubes (Dominique DUTSCHER, catalog number: 033252)

20. Peristaltic pump (Gilson Minipuls3)

21. Varian UNITY INOVA $500 \mathrm{MHz}$ NMR spectrometer equipped with a $10 \mathrm{~mm}$ broad band probe operating at $202.4 \mathrm{MHz}$ for ${ }^{31} \mathrm{P}$

\section{Software}

1. Microsoft Excel for calculations

2. Statistica 7.1 (StatSoft Inc., Tulsa, OK, USA) for statistical analysis

3. VnmrJ and ACDlabs for processing the ${ }^{31} \mathrm{P}-\mathrm{NMR}$ spectra 


\section{Procedure}

A. Preparation of fungal and plant cultures and subsequent plant-fungus incubation

1. Culture conditions for Hebeloma cylindrosporum

Mycelia were grown in glass jars according to the procedure previously described in Bio-protocol (Becquer et al., 2017a).

2. Culture conditions for Pinus pinaster

The procedure for disinfection of seeds, germination and culture conditions have been previously described in Bio-protocol (Becquer et al., 2017b).

3. Culture conditions for Zea mays

a. Sterilize the surface of seeds of maize (Zea mays L.) with a $6 \% \mathrm{H}_{2} \mathrm{O}_{2}$ solution for 30 min and rinse with sterile distilled water.

b. For germination, put the seeds between two sterile sheets of filter paper previously wetted with deionized sterile water. Incubate for 6 days at $30^{\circ} \mathrm{C}$ in the dark for germination.

C. Transfer the seedlings to the test tubes filled with a $0.2 \mathrm{mM} \mathrm{CaSO}_{4}$ solution ( $35 \mathrm{ml} /$ tube) for 3 days in a growth chamber chamber under $16 / 8 \mathrm{~h}$ light/dark cycle at $25^{\circ} \mathrm{C} / 20{ }^{\circ} \mathrm{C}, 80 \% / 100 \%$ $\mathrm{RH}, \mathrm{CO}_{2}$ volume fraction in air of $350 \times 10^{-6}$ and a photosynthetically active radiation of 400 $\mu \mathrm{mol} \mathrm{m} \mathrm{m}^{-2} \mathrm{sec}^{-1}(400-700 \mathrm{~nm})$.

d. Then, take the test tubes under a flow laminar cabinet to replace the $\mathrm{CaSO}_{4}$ solution by 35 $\mathrm{ml}$ of interaction medium (see Recipe 6) in each test tube. Return the test tubes into the growth chamber for an acclimatization period of $24 \mathrm{~h}$.

4. To study the plant roots signals eliciting a specific response of the fungal mycelia, follow the incubation procedure previously described in Becquer et al. (2017b).

B. Fungal sample preparation for in vivo NMR study

1. Preparation of equipment

a. A wooden skewer with a hook made with a nichrome wire at its end.

b. A glass capillary for the reference of chemical shift of NMR spectra (16.38 ppm), filled with a solution of methylene diphosphonate (MDP) $50 \mathrm{mM}$ in Tris buffer $30 \mathrm{mM}$ at pH 8.9 (see Video 1 how to prepare the capillary). 


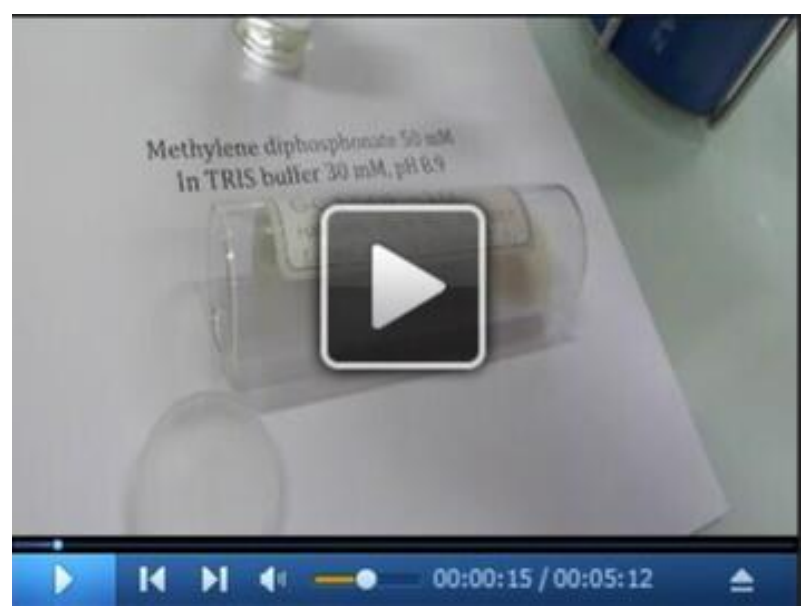

Video 1. Making the chemical shift reference with MDP solution

c. A special homemade NMR tube composed of 3 parts (see Figure 1 and Video 2)

i. An external NMR tube (10 $\mathrm{mm}$ diameter).

ii. An internal glass cylinder ( $7 \mathrm{~mm}$ diameter) which can be screwed on the external tube.

iii. A plastic cap on the top of this device which is bored to allow 3 Teflon tubings to connect the NMR tube to a peristaltic pump permitting the circulation of the oxygenated interaction medium. The inlet tubing extends to the bottom of the NMR tube. The output tubing extends to the top of the mycelia in the NMR tube. The end of the safety output tubing is $3 \mathrm{~cm}$ above the mycelia.

A string is attached to this device to allow its manual introduction into the hole in the magnet of the NMR spectrometer without using the air-lift system, to avoid friction between the 3 PVC tubings and magnet walls. 


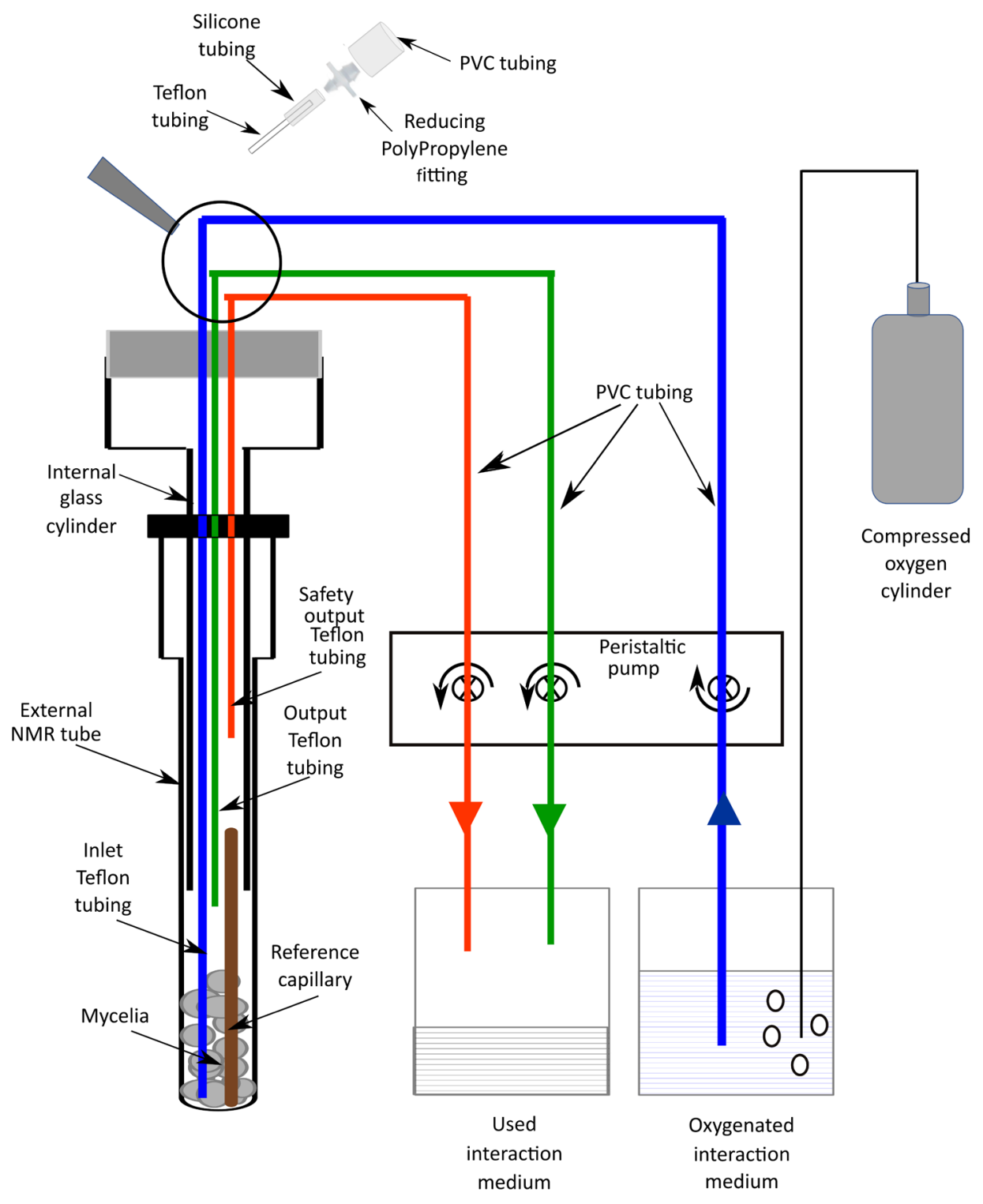

Figure 1. Scheme of the device used for in vivo ${ }^{31} \mathrm{P}$ NMR measurements

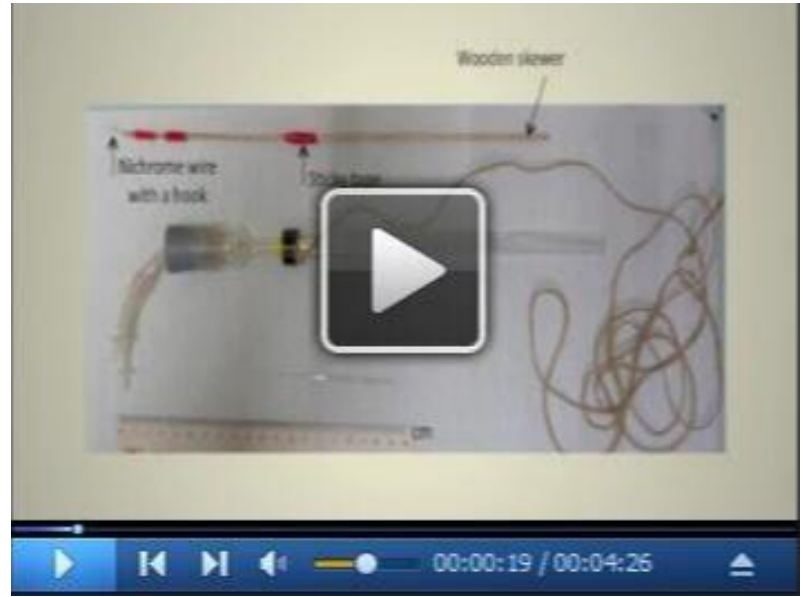

Video 2. Experimental set-up for in vivo NMR measurements 
d. A system that allows the circulation of the oxygenated interaction medium into the above-described tube, avoiding anoxia of the mycelia during the NMR data acquisition. It consists of:

i. The 3 Teflon tubings extending from the NMR tube that are connected to a peristaltic pump through PVC tubings.

ii. The inlet tubing supplies the interaction medium from a glass bottle $(2,000 \mathrm{ml})$, in which oxygen is bubbled from a compressed $\mathrm{O}_{2}$ gas cylinder, to the NMR tube.

iii. The output tubing collects the medium which has oxygenated the mycelia to another originally empty glass bottle $(2,000 \mathrm{ml})$.

iv. In case of dysfunction of the normal output system, a safety output tubing should avoid any leakage in the magnet hole.

2. Introduction of the fungal mycelia in the in vivo device NMR tube (see Video 2)

a. Remove the fungal mycelia from the flask, or from the syringe containing interaction medium (see Becquer et al., 2017b), let the solution drip off gently and put it on a filter paper with the help of spatula or tweezers.

b. Put the fungal mycelia at the bottom of the NMR tube, as gently as possible, using the spatula first and then the flat side of the wooden skewer. With Hebeloma cylindrosporum, three mycelial samples obtained in the above-described culture conditions are necessary for a reasonable signal to noise ${ }^{31} \mathrm{P}-\mathrm{NMR}$ of $1 \mathrm{~h}$ of fully relaxed data acquisition.

c. Put the chemical shift reference capillary at the bottom center of the NMR tube with the help of the wooden skewer and the hook.

d. Screw the internal tube on the NMR tube. If the reference capillary is not well positioned inside the internal tube, start again and move it with the hook to set it up in the middle of the internal tube.

e. Roll a silicone film on the plastic cap to ensure that the oxygenated perfusion solution will not leak off the NMR tube.

3. Starting the oxygenating perfusion system (adapted from Lee and Ratcliffe, 1983)

a. Start the oxygen bubbling in the glass bottle containing the interaction medium connected to the NMR tube via the inlet tubing.

b. Adjust the flow controlled by the peristaltic pump of the inlet, output and safety output tubings to $9 \mathrm{ml} \mathrm{min}^{-1}$ for each of them.

c. Introduce manually and slowly the NMR tube with the 3 tubings in the magnet hole of the NMR spectrometer with the help of the string.

C. Fungal sample preparation for in vitro NMR study (adapted from Roby et al., 1987)

1. Freeze the mycelia with liquid nitrogen.

2. Store them at $-80^{\circ} \mathrm{C}$ before extraction.

3. For each ${ }^{31} \mathrm{P}-\mathrm{NMR}$ measurement, thaw 6 frozen mycelia at $4{ }^{\circ} \mathrm{C}$ and crush them with $1 \mathrm{ml}$ of $70 \%$ $(\mathrm{v} / \mathrm{v})$ perchloric acid containing sodium vanadate $10 \mathrm{mM}$. 
4. Remove the particulate matter and neutralize the perchloric acid in the sample (adapted from Aubert et al., 1996):

a. Centrifuge the thick suspension at $10,000 \times g$ for $10 \mathrm{~min}$ to discard particulate matter in the pellet.

b. Transfer the supernatant into a $50 \mathrm{ml}$ Falcon tube, add a $\mathrm{pH}$ electrode and neutralize the solution by very slowly adding a solution of $2 \mathrm{M} \mathrm{KHCO}_{3}$, allowing foam to subside, stop when a $\mathrm{pH}$ of 6.5 is obtained.

c. Centrifuge again at $10,000 \times g$ for $10 \mathrm{~min}$ to remove $\mathrm{KClO}_{4}$ in the pellet.

d. Freeze dry the supernatant and store it at $-80^{\circ} \mathrm{C}$.

e. For the NMR measurement, the freeze-dried material is redissolved in $2 \mathrm{ml}$ MOPS $40 \mathrm{mM}$ (non-adjusted pH). Then add $0.2 \mathrm{ml}$ EDTA $100 \mathrm{mM}$. Adjust the $\mathrm{pH}$ to 7.8 with $\mathrm{KOH} 1 \mathrm{~N}$.

f. Add $\mathrm{NaN}_{3}$ to a final concentration of $100 \mathrm{mg} \mathrm{ml}^{-1}$ to avoid microbial degradation.

g. Add $\mathrm{D}_{2} \mathrm{O}$ (final concentration $10 \%$ ) for the field frequency lock of the NMR signal.

D. ${ }^{31} \mathrm{P}-\mathrm{NMR}$ data acquisition

1. Record NMR spectra with a Varian UNITY INOVA $500 \mathrm{MHz}$ operating at $202.4 \mathrm{MHz}$ for ${ }^{31} \mathrm{P}$ equipped with a $10 \mathrm{~mm}$ broadband probe operating at $25^{\circ} \mathrm{C}$.

2. For the in vivo experiments use the following parameters for acquisition conditions

a. It was not necessary to optimize shims considering the broadness of ${ }^{31} \mathrm{P} N M R$ signals in in vivo experiments. Carry out the experiments without a lock signal.

b. $90^{\circ}$ radio frequency pulses angle; spectral width $=20,000 \mathrm{~Hz}$; acquisition time $=0.4 \mathrm{sec}$; ${ }^{31} \mathrm{P}$ frequency offset $=3,900 \mathrm{~Hz}$. No decoupling (not useful considering the broadness of ${ }^{31} \mathrm{P}-\mathrm{NMR}$ peaks in vivo NMR experiments: ${ }^{1} \mathrm{H}$ decoupling does not affect the linewidths of peaks).

c. $20 \mathrm{sec}$ inter-scan delay (5 times the spin-lattice relaxation time T1) giving a fully relaxed spectrum (Quiquampoix et al., 1993). This is a very important parameter for the quantitative analysis of the chemical metabolites identified in the 31P-NMR spectrum. A much lower inter-scan delay does not allow a real quantification.

d. 180 scans giving a total accumulation time of $1 \mathrm{~h}$.

e. Apodization of the spectra using a $10 \mathrm{~Hz}$ exponential function and zero filling to $16 \mathrm{~K}$ points.

f. Phase and baseline correction.

Note: Examples of in vivo spectra obtained with this protocol can be seen in Torres-Aquino et al. (2017).

3. For the in vitro experiments use the following parameters for acquisition conditions

a. $10 \%$ of $\mathrm{D}_{2} \mathrm{O}$ in the mycelial sample as a lock signal.

b. $90^{\circ}$ radio frequency pulses angle; spectral width $=9,600 \mathrm{~Hz}$; acquisition time $=0.84 \mathrm{sec}$;

${ }^{1} \mathrm{H}$ decoupling during the acquisition time using a Waltz-16 pulse sequence at a field strength of $4 \mathrm{KHz} .{ }^{31} \mathrm{P}$ frequency offset $=4,900 \mathrm{~Hz} ;{ }^{1} \mathrm{H}$ frequency offset $=170 \mathrm{~Hz}$. 
c. $4 \mathrm{sec}$ inter-scan delay. In these experiments, the scope is the identification of the phosphorylated fungal metabolites based on the signal chemical shift, without the need of quantification. If quantification is required, use the $20 \mathrm{sec}$ inter-scan delay as for in vivo studies.

d. A sufficient number of accumulations for an acceptable signal-to-noise ratio.

e. Apodization of the spectra using a $2 \mathrm{~Hz}$ exponential function and zero filling to $16 \mathrm{~K}$ points

f. Phase and baseline correction.

Note: Examples of in vitro spectra obtained with this protocol can be seen in Torres-Aquino et al. (2017).

\section{Data analysis}

NMR peak areas of $\mathrm{Pi}$ and polyP are expressed relative to that of the MDP capillary which is the same for all experiments and is arbitrarily fixed to 1. If you compare several treatments, test the normality of data using the Kolmogorov Smirnov test and, where necessary, transform the data either square root or log10 prior to analysis to meet the assumptions of the ANOVA. To compare the effect of treatments, use an ANOVA analysis followed by Tukey's honest significance difference. For ${ }^{31} \mathrm{P}-\mathrm{NMR}$ measurements, data in percentage were transformed $(\arcsin \sqrt{x})$ as described by Legendre and Legendre (1998) before ANOVA.

\section{$\underline{\text { Notes }}$}

1. As the growth of the fungus in liquid medium may vary, we prepare up to 4 additional culture flasks inoculated with the fungus to discard those with poor growth.

2. If you need the assistance of a scientist who is in charge of an NMR facility unit, you will probably have to convince them of the safety of the homemade perfusion NMR tube for in vivo studies. Launch several distinct experiments with this device outside the NMR spectrometer to check that no leakage of liquid occurs.

3. If an NMR spectrometer of lower magnetic field is used, the number of accumulations will have to be increased.

4. The flow of oxygenated liquid medium in the perfusion NMR tube is a compromise between two unwanted phenomena: (i) a too low flow will not be sufficient for a good oxygenation of the cells and (ii) a too high flow will lead to bubbles formation in the matrix of the biological sample which causes a decrease in the spectral resolution. The latter effect usually does not appear below 10 $\mathrm{ml} \mathrm{min}{ }^{-1}$ (Lee and Ratcliffe, 1983). 


\section{Recipes}

1. Trace elements $(1,000 \mathrm{ml})$

$\begin{array}{ll}\mathrm{MnSO}_{4} \cdot \mathrm{H}_{2} \mathrm{O} & 3.08 \mathrm{~g} \\ \mathrm{ZnSO}_{4} \cdot 7 \mathrm{H}_{2} \mathrm{O} & 4.41 \mathrm{~g} \\ \mathrm{H}_{3} \mathrm{BO}_{3} & 2.82 \mathrm{~g} \\ \mathrm{CuSO}_{4} \cdot 5 \mathrm{H}_{2} \mathrm{O} & 0.98 \mathrm{~g} \\ \mathrm{Na}_{2} \mathrm{MoO}_{4} \cdot 2 \mathrm{H}_{2} \mathrm{O} & 0.29 \mathrm{~g}\end{array}$

Add $\mathrm{ddH}_{2} \mathrm{O}$ to $1,000 \mathrm{ml}$, store at $4{ }^{\circ} \mathrm{C}$

2. Mineral salt base solutions (100 $\mathrm{ml}$ each)

\begin{tabular}{|c|c|}
\hline Solutions & For making $100 \mathrm{ml}$ \\
\hline $1 \mathrm{M} \mathrm{KNO}_{3}$ & $10 \mathrm{~g}$ \\
\hline $1 \mathrm{M} \mathrm{NaH}_{2} \mathrm{PO}_{4} \cdot \mathrm{H}_{2} \mathrm{O}$ & $13.8 \mathrm{~g}$ \\
\hline $1 \mathrm{M} \mathrm{MgSO}_{4} \cdot 7 \mathrm{H}_{2} \mathrm{O}$ & $24.6 \mathrm{~g}$ \\
\hline $1 \mathrm{M} \mathrm{KCl}$ & $7.45 \mathrm{~g}$ \\
\hline $1 \mathrm{M} \mathrm{CaCl}_{2} \cdot 2 \mathrm{H}_{2} \mathrm{O}$ & $7.35 \mathrm{~g}$ \\
\hline $1 \%$ ferric ammonium citrate & $1 \mathrm{~g}$ \\
\hline
\end{tabular}

3. Thiamine solution $(100 \mathrm{ml})$

Thiamine- $\mathrm{HCl}$

4. N6 complete liquid solution $(1,000 \mathrm{ml})$

a. Add in a $1 \mathrm{~L}$-beaker approximately $500 \mathrm{ml}$ of deionized water and the following volumes of mineral base solutions:

$\begin{array}{ll}\mathrm{KNO}_{3} & 6 \mathrm{ml} \\ \mathrm{NaH}_{2} \mathrm{PO}_{4} & 1 \mathrm{ml} \\ \mathrm{MgSO}_{4} & 1 \mathrm{ml} \\ \mathrm{KCl} & 4 \mathrm{ml} \\ \mathrm{CaCl}_{2} & 0.5 \mathrm{ml} \\ \text { Ferric ammonium citrate } & 0.5 \mathrm{ml}\end{array}$

b. Add also trace elements $0.2 \mathrm{ml}$ and thiamine solution $0.5 \mathrm{ml}$

c. Complete the volume to $1 \mathrm{~L}$ and check the $\mathrm{pH}$ which should be adjusted to 5.5

d. Finally, add $5 \mathrm{~g}$ of D-glucose and shake until complete dissolution

e. Distribute this solution into glass jars

5. Solid $\mathrm{N} 6$ complete liquid solution $(1,000 \mathrm{ml})$

Take two $1 \mathrm{~L}$ glass bottles:

a. Add $7.5 \mathrm{~g}$ of Agar-agar and pour $500 \mathrm{ml}$ of liquid $\mathrm{N6}$ medium in each bottle

b. Sterilize the medium by autoclaving at $121^{\circ} \mathrm{C}$ for $20 \mathrm{~min}$

c. Pour the cooled medium $\left(55-60{ }^{\circ} \mathrm{C}\right)$ in Petri dishes $90 \mathrm{~mm}$ diameter 
6. Interaction medium $(3,000 \mathrm{ml})$

a. Add in a $3 \mathrm{~L}$-beaker approximately $1.5 \mathrm{~L}$ of deionized water and the following volumes of mineral base solutions:

$\begin{array}{ll}\mathrm{MgSO}_{4} & 0.6 \mathrm{ml} \\ \mathrm{CaCl}_{2} & 1.5 \mathrm{ml} \\ \mathrm{MES} \text { (final concentration of } 5 \mathrm{mM} \text { ) } & 3.2 \mathrm{~g} \\ \text { TRIS (final concentration of } 5 \mathrm{mM} \text { ) } & 1.82 \mathrm{~g}\end{array}$

b. Complete to $3 \mathrm{~L}$ with deionized water and adjust the $\mathrm{pH}$ to 5.5 with $1 \mathrm{~N} \mathrm{H}_{2} \mathrm{SO}_{4}$

c. Pour $1.5 \mathrm{~L}$ of medium into $2 \mathrm{~L}$ glass bottles and sterilize by autoclaving $\left(20 \mathrm{~min}, 121^{\circ} \mathrm{C}\right)$

\section{Acknowledgments}

This research was supported by INRA (France) through a Young Scientist Contract granted to Adeline Becquer and by CONACYT (Mexico) through a Ph.D. fellowship granted to Margarita Torres-Aquino. The protocol is adapted from our previous work (Torres-Aquino et al., 2017).

\section{Competing interests}

The authors declare that they have no conflicts of interest.

\section{References}

1. Ashford, A. E., Ryde, S. and Barrow, K. D. (1994). Demonstration of a short chain polyphosphate in Pisolithus tinctorius and the implications for phosphorus transport. New Phytologist 126(2): 239-247.

2. Aubert, S., Gout, E., Bligny, R., Marty-Mazars, D., Barrieu, F., Alabouvette, J., Marty, F. and Douce, R. (1996). Ultrastructural and biochemical characterization of autophagy in higher plant cells subjected to carbon deprivation: control by the supply of mitochondria with respiratory substrates. J Cell Biol 133(6): 1251-1263.

3. Becquer, A., Torres-Aquino, M., Le Guernevé, C., Amenc, L.K., Trives-Segura, C., Staunton, S., Quiquampoix, H. and Plassard, C. (2017a). A method for radioactive labelling of Hebeloma cylindrosporum to study plant-fungus interactions. Bio-Protocol 7(20): e2576

4. Becquer, A., Torres-Aquino, M., Le Guernevé, C., Amenc, L.K., Trives-Segura, C., Staunton, S., Quiquampoix, H. and Plassard, C. (2017b). Establishing a symbiotic interface between cultured ectomycorrhizal fungi and plants to follow fungal phosphate metabolism. Bio-Protocol 7(20): e2577

5. Cairney, J. W. G. (2011). Ectomycorrhizal fungi: the symbiotic route to the root for phosphorus in forest soils. Plant Soil 344: 51-71. 
6. Lee, R. B. and Ratcliffe, R. G. (1983). Development of an aeration system for use in plant tissue NMR experiments. Journal of Experimental Botany 34(146): 1213-1221.

7. Legendre, P. and Legendre, L. (1998). In: Numerical Ecology. 2nd edition. pp. 33-46. Elsevier Science B. V. Amsterdam.

8. Plassard, C. and Dell, B. (2010). Phosphorus nutrition of mycorrhizal trees. Tree Physiol 30(9): 1129-1139.

9. Quiquampoix, H., Bačić, G., Loughman, B. C. and Ratcliffe, R. G. (1993). Quantitative aspects of the ${ }^{31} \mathrm{P}-\mathrm{NMR}$ detection of manganese in plant tissues. $J$ Exp Bot 44(269): 1809-1818.

10. Quiquampoix, H. and Mousain, D. (2005). Enzymatic hydrolysis of organic phosphorus. In: Organic Phosphorus in the Environment, pp. 89-112. In: Turner, B. L., Frossard, E. and Baldwin, D. (Eds.). CAB International. Wallingford.

11. Roby, C., Martin, J. B., Bligny, R. and Douce, R. (1987). Biochemical changes during sucrose deprivation in higher plant cells. Phosphorus-31 nuclear magnetic resonance studies. $J$ Biol Chem 262(11): 5000-5007.

12. Smith, S. E. and Read, D. J. (2008). Mycorrhizal symbiosis. 3rd edition. Academic Press, London.

13. Smith, S. E., Anderson, I. C. and Smith, F. A. (2015). Mycorrhizal associations and phosphorus acquisition: from cells to ecosystems. Annual Plant Reviews 48: 409-440.

14. Torres-Aquino, M., Becquer, A., Le Guerneve, C., Louche, J., Amenc, L. K., Staunton, S., Quiquampoix, H. and Plassard, C. (2017). The host plant Pinus pinaster exerts specific effects on phosphate efflux and polyphosphate metabolism of the ectomycorrhizal fungus Hebeloma cylindrosporum: a radiotracer, cytological staining and ${ }^{31} \mathrm{P}$ NMR spectroscopy study. Plant Cell Environ 40(2): 190-202. 